\title{
A CELTIC GOLD STATER FROM THE VICINITY OF RADOBOJ (CROATIA)
}

\author{
Peter Kos \\ Šujica 107 \\ SI - 1356 Dobrova \\ peter.kos@nms.si
}

UDK / UDC: 069.5(497.521.2):737.1

Izvorni znanstveni rad / Original scientific paper

https://doi.org/10.52064/vamz.54.1.1

Around 1840, a gold coin was discovered near Radoboj (northwestern Croatia), a Celtic imitation of a gold stater of Alexander III of type Athena/Nike. In 2019, during archaeological excavation of the Roman temple at Frauenberg, near Leibnitz (Austria), two imitations of staters of the same type were excavated. Of these, one coin was minted with the same dies for obverse and reverse as the coin from Radoboj, which undoubtedly testifies to minting in the same mint. In the area of north-western Croatia and eastern Slovenia, four other Athena/Nike staters can be documented

Key words:

Alexander's Athena/Nike staters, Celtic gold coins, local imitations, $3^{\text {rd }}$ C. BC Croatia, Slovenia, Austria

In the collection of Greek coins of the Numismatic Department of the Archaeological Museum in Zagreb, among the gold coins of the Macedonian king Alexander III (336-323 BC), a stater that was acquired by the museum as a purchase from the collection of $\mathrm{Dr}$ Ljudevit Gaj is also preserved. "Radoboj, pod gorom" (Radoboj, under the mountain) is listed as the site. The coin was discovered around 1840 by a farmer north of the settlement of Radoboj at at four other sites. To date, 83 Athena/Nike imitations have been discovered in Central Europe, of which 32 coins originate from 26 sites. Seven coins from six sites in the area south of the middle course of the Mura and Drava rivers therefore significantly complement the current record of finds of these earliest Celtic coin finds in Central Europe. At the same time, it proves that the minting of this group of imitations can be attributed to the local Celtic tribes sometime in the middle of the $3^{\text {rd }}$ century $B C$.
$1 \quad$ Ljubić 1890, 40 (weight stated as $8.5 \mathrm{~g}$ ). the foot of the Strahinjčica mountain in Krapina-Zagorje County (north-western Croatia). ${ }^{2}$ It was bought from him by the parish priest of Krapina, Janko Bedenko, and then handed over to Ljudevit Gaj, who later sold it to the Archaeological Museum in

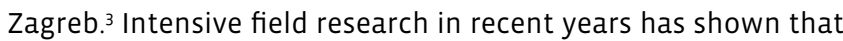
the wider area of Radoboj was intensively populated from the Palaeolithic to the Late Iron Age. ${ }^{4}$
Klemenc, Saria 1936, 64; Mirnik 1989, 37; Registar 1997, 80, no. 182; Špoljar 2014, 39; 2015, 118.

Ljubić 1880, 119; Mirnik 1990, 4.

Špoljar 2014; 2015. 


\section{Description of the coin}

\section{Stater}

Obv:: The head of Athena with a crested Corinthian helmet, to the right.

Rev.: The winged Nike stands to the left. She has her left arm lowered next to her body, holding a mast, of which only the extension can be seen above her left wing. She holds a poorly recognizable wreath in her outstretched right hand. On the right edge of the coin is the inscription $A \wedge E \equiv A \cap$ in primitive letters; on the left edge of the coin is also a primitive inscription, $\Sigma \mathrm{A}-\mathrm{CI} \Lambda$.

\section{ZG 1188}

Radoboj, under the mountain

Ex collection Dr Ljudevit Gaj

Weight: $8.46 \mathrm{~g}$; diameter: $17 \times 19 \mathrm{~mm}$; die axis: $12 \mathrm{~h}$

Undoubtedly, the gold coin from the vicinity of Radoboj is an imitation of an Athena/Nike stater of the Macedonian king Alexander III (336-323 BC). ${ }^{5}$ The depiction of Nike on the back of the coin is of quite primitive execution, and the letters on the inscription on the right and left edges of the coin further indicate that the die cutter was not proficient in Greek script.

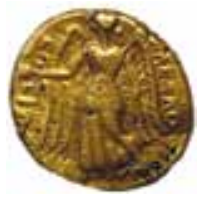

Scale $=1: 1$
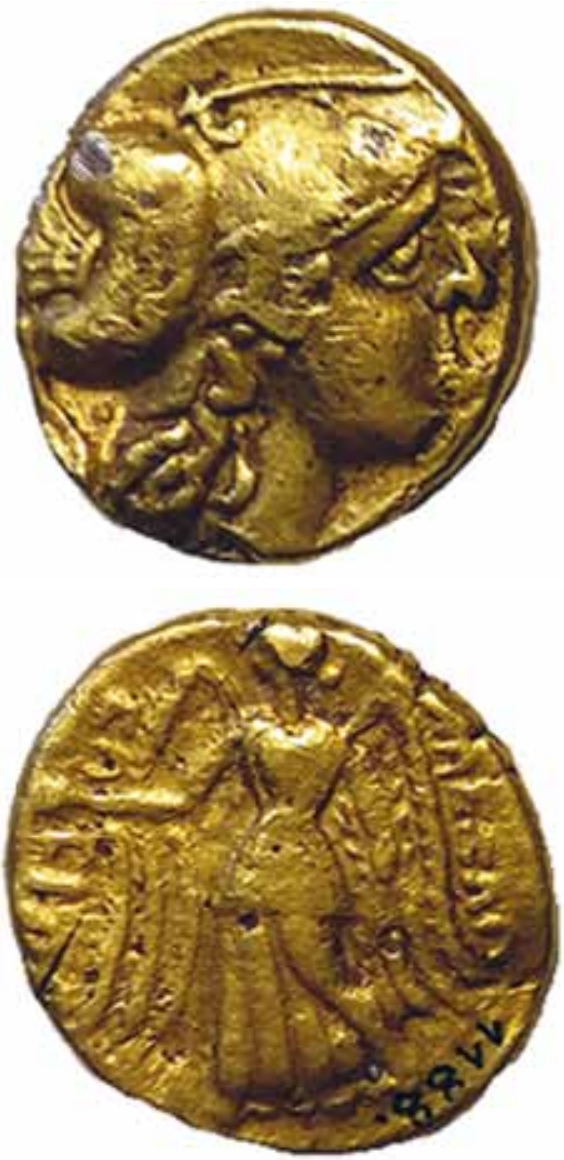

Scale $=3: 1$ 


\section{Prototypes for the local gold coinage}

It is widely known that the beginning of the minting of the earliest Celtic coins in Central Europe was influenced by the gold staters of the Macedonian king Alexander III. ${ }^{6}$ These had a depiction of the head of Athena, to the right, with a crested Corinthian helmet decorated with a twisted serpent on the obverse. On the reverse, a standing Nike with a wreath in her right hand and a mast (stylis) in her left was depicted. Symbols or monograms used to denote mints and their emissions can often be found to the left and right of Nike. ${ }^{7}$ On the reverse of coins of this type, the inscription $A \wedge E \equiv A N \triangle P O Y$ can be found on the right edge, less

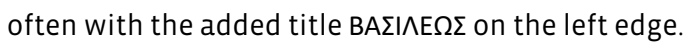

The weight of Alexander's staters ranges between $8.40 \mathrm{~g}$ and 8.65 $\mathrm{g}$ (most specimens weighing between $8.48 \mathrm{~g}$ and $8.62 \mathrm{~g}$ ), with no noticeable difference between the staters minted during his reign and the posthumous issues of his coins. ${ }^{8}$

Staters depicting Nike on the reverse were first minted in mints in Macedonia, and then their minting spread rapidly throughout the Greek world. During the reign of Alexander III (336-323 $\mathrm{BC}$ ), his staters were minted in 18 of the 26 mints in operation at the time. ${ }^{9}$ In particular, the quantity of coins increased during the period 325-323 BC, which can be linked to the payment of severance pay upon the return of mercenaries from the east. ${ }^{10}$ In the period 323-317 BC, during the reign of Philip III Arrhidaeus (323-317 BC), Alexander's coins were posthumously minted in 31 mints, including gold coins in 23 mints. ${ }^{11}$ Between 317 and 300 BC, 27 mints were in operation, and in 20 mints Alexander's staters were minted posthumously. ${ }^{12}$ Afterwards, a decreasing number of gold staters minted in the name of Alexander III can be observed; however, up to about $200 \mathrm{BC}$ they were still minted in the Black Sea mints. It is believed that coinage was minted there to pay off Celtic tribes as compensation for non-aggression until about $200 \mathrm{BC} .{ }^{13}$

The title $B A \Sigma I \Lambda E \Omega \Sigma$ on the reverse of the gold staters of Alexander III first appeared during his reign in the mint of Babylon, in southern Asia Minor, and in Phoenicia (as this title was unpopular with the Greeks) on series with which veterans returning home in 324 $\mathrm{BC}$ were paid. ${ }^{14}$ Alexander's gold staters with this title were then minted until about $200 \mathrm{BC}$, whereas in the zrd century BC staters with the name $B A \Sigma I \wedge E \Omega \Sigma$ were minted only in the Black Sea mints.
As payment to Celtic mercenaries in the Macedonian army or as spoils of war (trade contacts are less likely), Alexander's staters penetrated into the Balkans (especially Bulgaria, Romania and Serbia ${ }^{15}$ and Central Europe, as shown by some hoards containing his gold coins, as well as finds of individual specimens from Hungary, Moravia and Slovakia. ${ }^{16}$

Despite the intensive production of staters in Alexander's name from the beginning of his reign and after his death until the end of the $3^{\text {rd }}$ century $B C$, it seems that the gold coins minted during Alexander's lifetime or immediately after his death, i.e. towards the end of the $4^{\text {th }}$ century $\mathrm{BC}$, predominated in penetrating into the Celtic world.

This is shown by coin hoards from the end of the $4^{\text {th }}$ century BC from this area, ${ }^{17}$ as well as the coin hoards of the early $3^{\text {rd }}$ century BC where Alexander's early staters from the $4^{\text {th }}$ century $B C$ are represented. ${ }^{18}$ For instance, Alexander's stater in the hoard of Celtic tetradrachms of Nagyhörcsökpuszta (Hungary), which was buried in the $2^{\text {nd }}$ century $B C$, was minted in the Amphipolis mint during Alexander's lifetime. ${ }^{19}$

\section{Imitations of Alexander's staters of the Athena/Nike type}

It seems that these early staters of Alexander then predominantly served as a model for the earliest local coinages of Celtic tribes in Central Europe. In his first group of Celtic imitations of Alexander's gold staters, J. Militký listed 17 coins. Of these, 11 specimens imitated early staters of Alexander III minted during his reign or immediately afterwards. For specimens $1: 01.1 / 1$, I:01.1/2, I:01.1/3, I:01.2/1 and I:01.3/1, prototypes from the mint of Amphipolis, 330-320 BC, were used, while for coins $1: 01.4 / 1$, I:01.4/2, I:01.4/3, I:01.4/4, I:01.4/5 and I:01.5/1, the prototypes originated from the mint of Memphis, 323-316 BC. To this group (I:01), a stater from St Peter in Holz (Carinthia, in Austria) should also be added, which similarly was minted on the model of the Amphipolis mint (330-320 BC). ${ }^{20}$

Finds of imitations of Alexander's staters have been documented mainly in the territory of the modern Czech Republic, Moravia and north-eastern Austria, the area traditionally associated with the settlement of the Boii. Consequently, these early imitations of Alexander's staters are thus usually attributed to Celtic tribes
5 Dukat, Mirnik 1976, 190, PI. 4: 56 (photo of the wrong coin: weight and diameter do not match). Mirnik 2008, 189, cat. no. 111; Bilić 2017, 228, 240, cat. no. 21. Briefly mentioned by Bilić 2012, 360, no. 30.

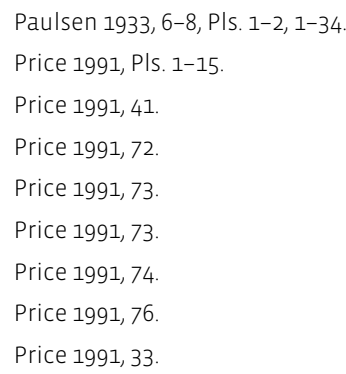

15 Price 1991, 66, no. 1. Torbágyi 1991, 26-29 manages to document only a small number of Alexander's staters in the Balkans and the Carpathian Plain: 19 individual finds of his staters in Romania ( $12 x)$, in Hungary $(2 x)$, in Banat in the former Yugoslavia ( $4 \mathrm{x}$ ), and 1 specimen in Croatia. Two hoard finds of Alexander's staters have been documented from the area of Romania, while in only one hoard find in Hungary has a stater of Alexander been discovered together with Celtic tetradrachms. For Bulgaria see Paunov 2015, 270.

16 See Militký 2018a, 20

17 See the list of hoards by Price 1991, 47-50

18 Price 1991, 57

19 Torbágyi 2016, 132.

20 Pichler 1887, xcix. Most probably type Militký 1:01.1/1. 
of the Boii. ${ }^{21}$ Only individual specimens are also documented in Poland, Slovakia, Hungary, Austria and Germany.22 Most imitations of Alexander's staters of the Athena/Nike type are documented in the area of central and eastern Bohemia and central and southern Moravia, where it is possible to locate the operation of the mints of these staters. ${ }^{23}$

K. Castelin assumed that not only Alexander's original staters but also imitations of these coins, minted by Celtic tribes in the Balkans and the Carpathian Basin, penetrated into the territory of Moravia and later the Czech Republic. ${ }^{24}$ This assumption is also followed by some recent authors, who allow for the possibility that imitations of staters came to Moravia, Slovakia and the Czech Republic with returning Celtic soldiers from the Balkans. ${ }^{25}$ This seems unlikely, as the Celtic tribes in the Balkans and in present-day Romania minted exclusively silver coins. ${ }^{26}$ Finds of imitations of Alexander's staters in this area are extremely rare. Transylvania (Romania) was probably the source of specimen Militký I:01.4/3 (1) (prototype stater of the mint of Memphis from $323-316 \mathrm{BC}){ }^{27}$ and the coin of the Osijek Museum (prototype stater of the mint of Lampsacus from 328-323 BC) ${ }^{28}$.

J. Militký dealt in detail with the problem of imitations of Alexander's staters with the Athena/Nike motif, which he managed to divide into 17 groups. ${ }^{29}$ The groups range from coins showing all the characteristics of the Greek style, which have on the right edge of the reverse of the coin a legible Greek inscription and often a symbol of the mint that served as a model (group I:01), 30 to heavily barbarized specimens (groups 1:06, I:09, I:12-14). ${ }^{31}$ Some groups include coins that show a strong stylistic diversity. All these coins belong to numismatic horizon $A 1$, which corresponds to archaeological horizon Lt $\mathrm{B}_{2}$ or to the $\mathrm{Lt} \mathrm{B}_{2} / \mathrm{C}_{1}$ transition, and Militký places this group in absolute chronological terms between 300 and 260/250 BC, when the oldest Celtic coins in Central Europe were minted. ${ }^{32}$ Militký seems to be more inclined to the middle of the 3 rd century $B C$ when dating the introduction of minting of this earliest coinage in Central Europe. ${ }^{33}$
In his outstanding study, Militký was able to collect 83 imitations of Alexander's Athena/Nike-type staters, of which only 73 coins are physically preserved. Of 83 imitations, 35 specimens originate from 26 sites. I am convinced that the two imitations in silver that Militký classifies to group I:17 cannot be included in this group of imitations. ${ }^{34}$

According to this evidence, Militký placed the minting of this coinage on the territory of central Bohemia and along the amber route in Moravia and Lower Austria north of the Danube. ${ }^{35}$

The gold coin from Radoboj can be classified into Militký's group I:05, which is characterized by an inscription on both sides of

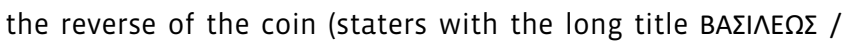
$\mathrm{A} \wedge \mathrm{E} \equiv \mathrm{AN} \triangle \mathrm{POY}$, which served as a model) and which still shows to a certain extent - the Greek style of depiction. In this group Militký managed to document 12 coins $^{36}$ which are stylistically quite diverse. of these, four specimens originate from the Moravian region (three specimens from the settlement of Němčice nad Hanou). In Austria (Linz?) and Hungary (Nagysánc) only two individual specimens have been found..$^{37}$ The weight of the coins of this group ranges between $8.2 \mathrm{~g}$ and $8.5 \mathrm{~g}$, and they were minted from metal of varied purity, as the gold content ranges between 93 and $99 \% .^{38}$

\section{The dating of the gold coin from Radoboj}

Dating the minting of imitations of Alexander's staters with a depiction of Nike on the reverse is very difficult, as these coins are rarely discovered in well-stratified archaeological contexts. Even when excavated in clear and undisputed archaeological strata, they can only be roughly dated. Thus, coin I:01.4/1(1) from the Celtic settlement of Trepcza in Poland originates from the period Lt B2/C $1 .{ }^{39}$ Three imitations of Alexander's staters (I: 05.1/1(1), I:05.1/10(1) and I:05.1/11(1)) originate from the Celtic settlement of Němčice, in Moravia. The archaeological layers in which these coins were found can only roughly be classified

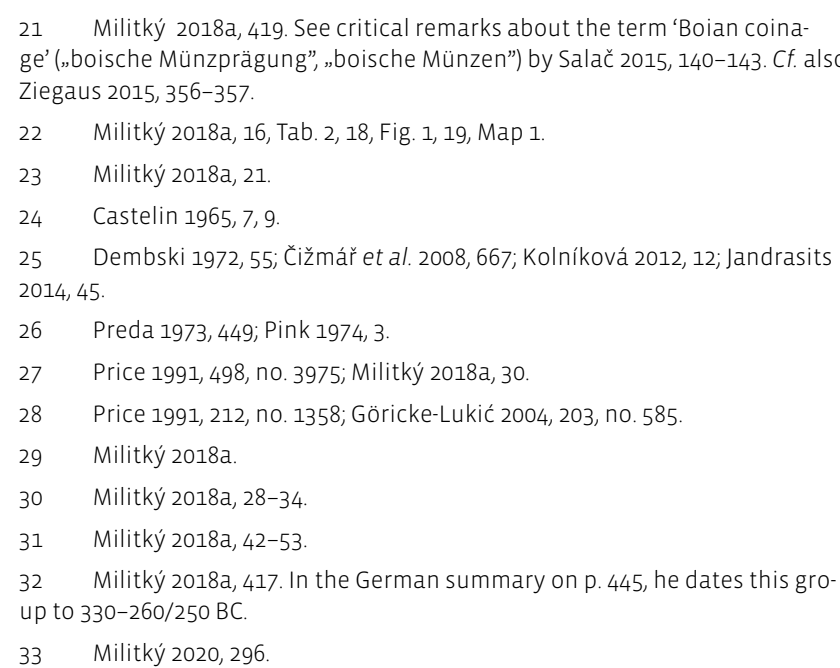

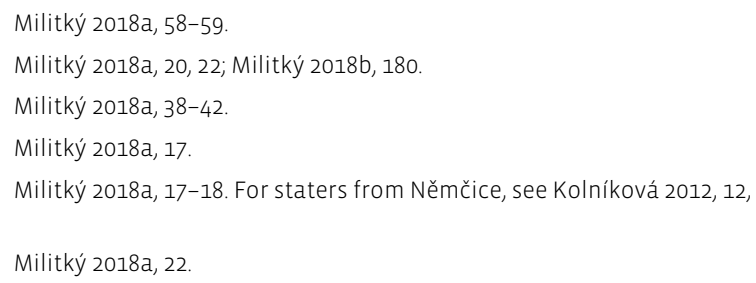


to the period from the end of $L t B 2$ to $C 2$, which corresponds in absolute chronological terms to the period from the end of the first half of the $3^{\text {rd }}$ century $B C$ to the middle of the $2^{\text {nd }}$ century $B C$. Based on the relatively great weight of Alexander's staters from the Němčice site, E. Kolníková places their minting in the period between the end of the $4^{\text {th }}$ century $B C$ and the second half of the $3^{\text {rd }}$ century BC. $4^{0}$

The fact that three Athena/Nike staters were included in the Nechanice coin hoard, which was buried at the turn of the $2^{\text {nd }}$ century $B C,{ }^{41}$ does not contribute much to the problem of the beginning of their minting.

To establish a more detailed chronology of imitations of the staters of Alexander III, the find of two staters in a ceramic vessel (presumably with a seal decoration) from a grave in a mound in Dobian, in central Germany (Thüringen), is considered to be of great importance..$^{2}$ However, only one stater (Militký I:01.4/5(1)) and a bronze ring have been preserved from the grave inventory. The tomb was dated by $\mathrm{H}$. Polenz to Lt B2 and the transition to $\mathrm{C}_{1}(?),{ }^{43}$ and for both coins from the tomb he assumed that they belonged to the time around the middle of the $3^{\text {rd }}$ century BC.44 The tomb was also placed by B. Ziegaus at a time in, or just before, the middle of the $3^{\text {rd }}$ century BC. ${ }^{45}$ On this basis, he concluded that the minting of both imitations in the tomb can be placed in Lt B2b, which corresponds to the first half of the $3^{\text {rd }}$ century $\mathrm{BC}$, and, consequently, he dated the beginning of coinage of imitations of Alexander's Athena/Nike staters back to the turn of the $3^{\text {rd }}$ century $B C .4^{46}$ Militký places the end of the minting of the Athena/Nike imitations at the Lt B2/C1 transition. ${ }^{47}$

On the basis of this evidence, it can be seen that the determination of the beginning of the minting of different variants of imitations of the staters of Alexander III, in the absence of tangible archaeological data, is to a certain extent arbitrary.
Bilic is convinced that the higher weight of the staters from Radoboj and Ludbreg (8.46 and $8.21 \mathrm{~g}$, respectively) would suggest an early date of minting ( $L t$ B2, 320-260 BC).48

It seems to me, however, that we need to place the minting of these coins a few decades later, and I would rather suggest the second quarter of the $3^{\text {rd }}$ century $\mathrm{BC}$. Judging by the star-like mint-mark (right below the wing of Nike) on the reverse of the coin from Ludbreg, ${ }^{49}$ Alexander's stater minted at the Amphipolis mint between 294 and 290 BC was most likely used as the proto type for its minting, ${ }^{50}$ hence implying a later production of these imitations.

\section{Analogies for the coin from the vicinity of Radoboj}

The imitation of Alexander's stater from Radoboj is not an isolated example of the discovery of this kind of coinage in the area south of the lower Drava river basin. Thus, an imitation, which can be classified into the thirteenth group of imitations according to Militký, ${ }^{51}$ is known from the vicinity of Ludbreg (Croatia), ${ }^{52}$ and an imitation of Alexander's stater (type Paulsen 36) has also been discovered in the vicinity of Varaždin (Croatia). ${ }^{53} \mathrm{An}$ imitation of Alexander's stater was also discovered in Slovenska Bistrica (Slovenia) around 1900, but the coin, which has not been preserved, is not described in detail. ${ }^{54}$ In 2018, a similar type of imitation as that known from the vicinity of Varaždin was discovered in skeletal grave no. 11 of the Late Iron Age site at Podzemelj in Bela Krajina (Slovenia). 55 In 2019, during archaeological excavations of the Roman sanctuary at Frauenberg near Leibnitz, west of the Mura river in Styria (Austria), two imitations of Alexander III's stater were excavated, one of which can be classified into Militký's fifth group, and one into his eighth group. ${ }^{56}$ Both coins were excavated in a Late Roman context. ${ }^{57}$ It should be noted that the coins from Varaždin and Podzemelj have a lower weight and show a specific style that differs from other gold coins of the Athena/Nike type..$^{58}$

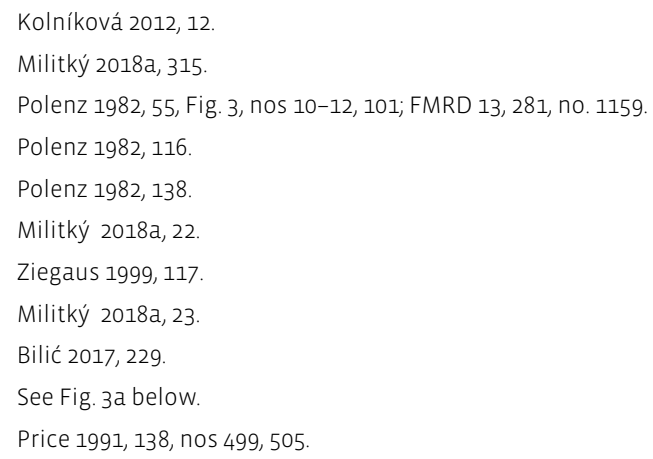

51 Militký 2018a, 46-48.

52 Dukat, Mirnik 1976, 190, PI. 4, 58 (wrong photo). Photo in Mirnik 2008, 120, Fig. 2; Bilić 2017, 241, cat. no. 23.

53 Bilić 2017, 241, cat. no. 24

54 Kos 1977, 138, no. 29.

55 Grahek, Kovač 2020, 448, 449, Fig. 10. A detailed study of the coin is being prepared by P. Kos.

56 Schrettle, Peitler 2019.

57 Schrettle, Peitler 2019, 32

58 On the basis of the lower weight of the specimen from Varaždin, Bilić

2017, 229 proposed its minting in the period Lt C 1 (260-200 BC).

59 Militký 2018a, 40, 41, var. I:05.1/8(1).

60 Militký 2018, 19, Fig. 1. 


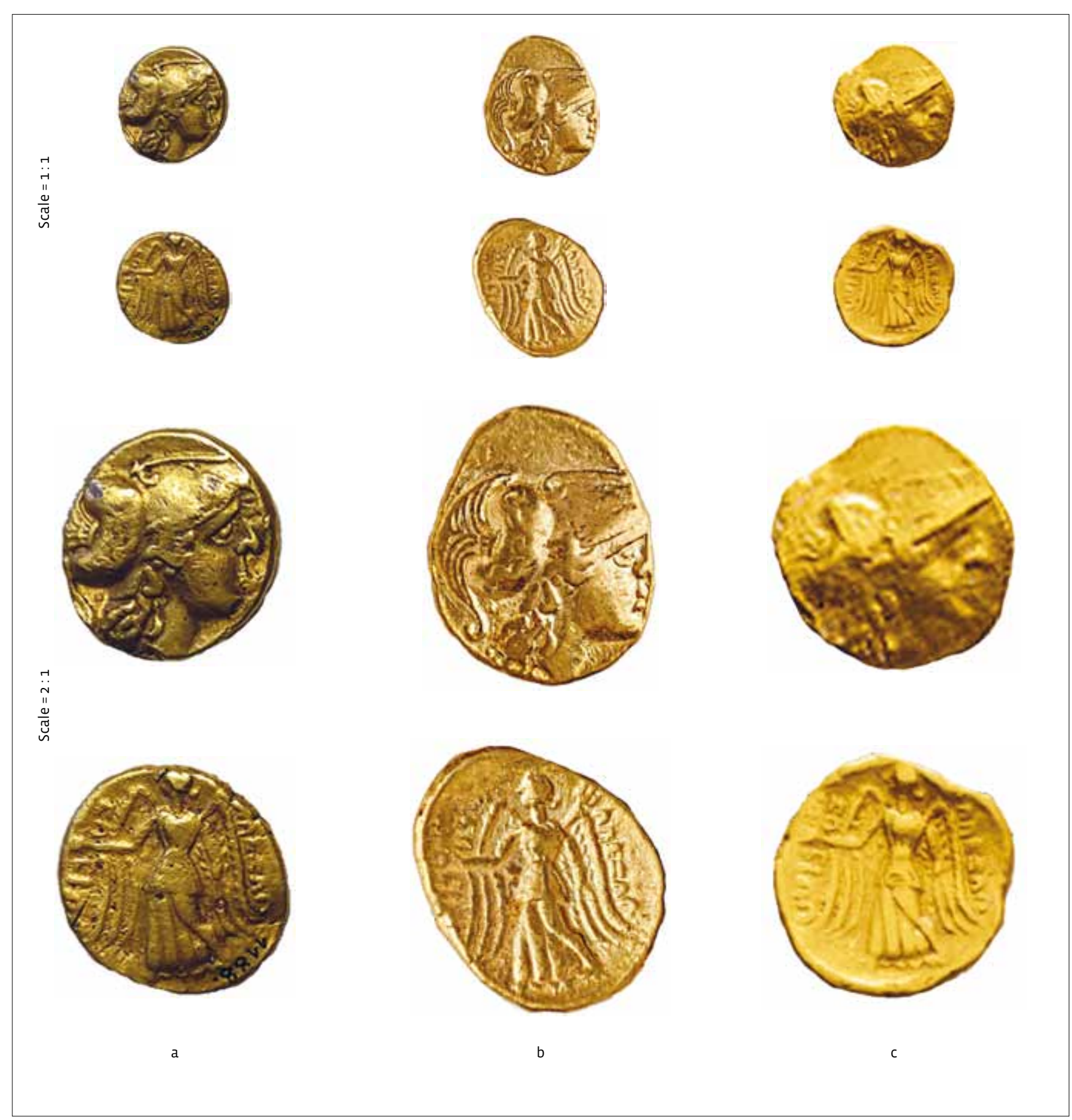

FIGURE 2. Direct analogies for the coin from the vicinity of Radoboj: a) Radoboj; ZG 1188; $8.46 \mathrm{~g} ; 17 \times 19 \mathrm{~mm} ; 12 \mathrm{~h}$ (photo by P. Kos); b) Frauenberg, $8.47 \mathrm{~g}$; $23 \times 18 \mathrm{~mm}$; $12 \mathrm{~h}$ (Schrettle, Peitler 2019, 31, Abb. 1a-b); c) no provenance data; Staatliche Münzsammlung, München, MC 1208; 8.52 g; 19.6 mm; 12 h (Militký 2018, I:05.1/8(1).

A detailed comparison of imitations of Alexander's gold staters from this area shows that the coin from the vicinity of Radoboj, and coin no. 1 from Frauenberg, can be classified into the same eighth variant of the fifth group of imitations as the coin without provenance that is kept in the Staatliche Münzsammlung in Munich. ${ }^{59}$ Both the coin from the vicinity of Radoboj and coin no. 1 from Frauenberg were minted with the same die for the reverse of the coin with which the coin from Munich was also minted.
The obverse of the coins from Radoboj and Frauenberg was also minted with the same die. The coin from Munich was probably also minted with the same obverse die, but at the time of minting the die for the latter had already been heavily used. Based on the fact that all three coins were minted with the same dies for the obverse and reverse, it can be concluded that they originated from the same mint. 


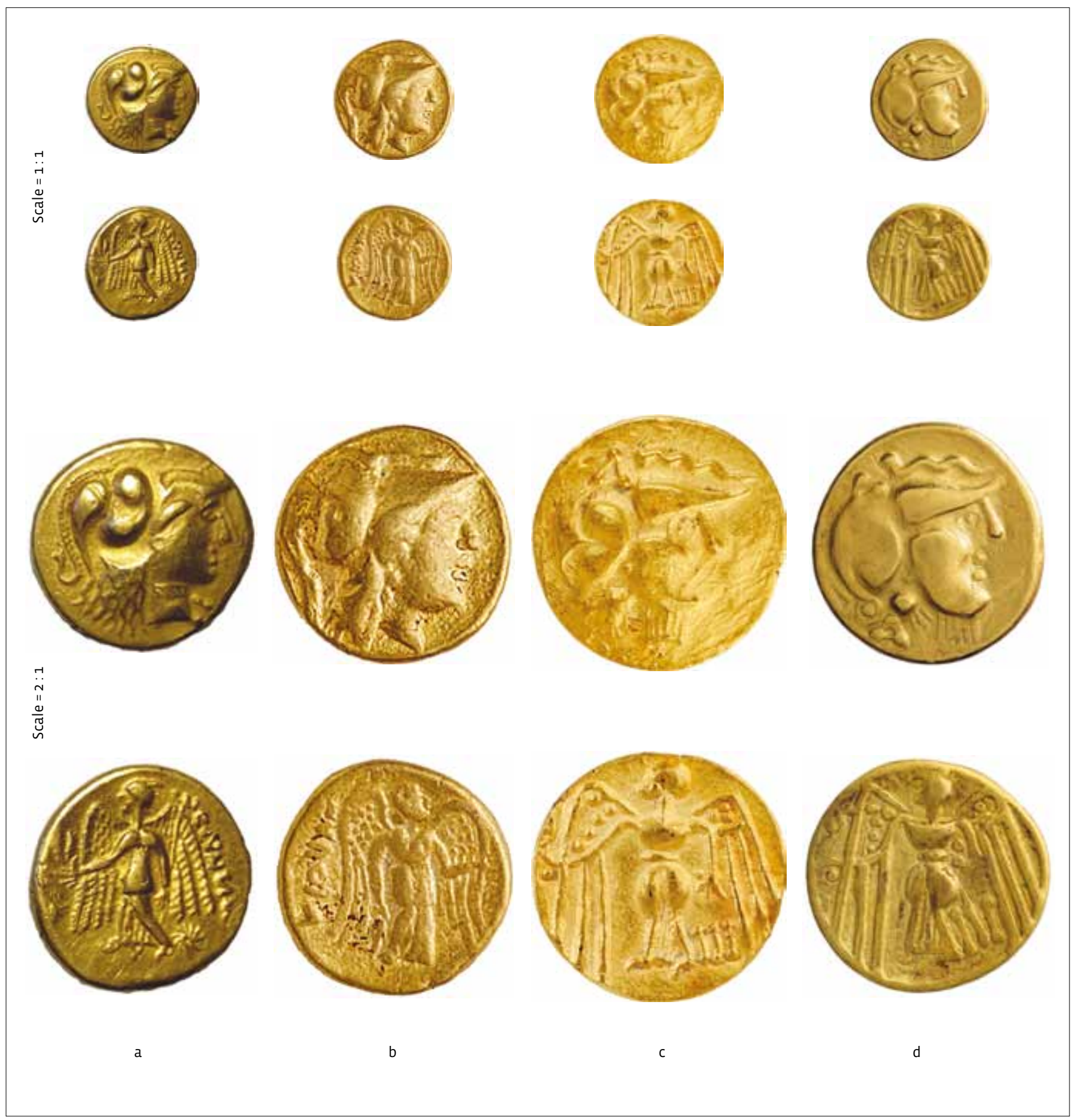

FIGURE 3. Celtic gold coins from the area south of the Mura and Drava rivers: a) Ludbreg; ZG 4674; $8.21 \mathrm{~g} ; 17.5 \times 18.5 \mathrm{~mm}$; 1 h (photo by I. Krajcar); b) Frauenberg; 8.45 g; 19 mm (Schrettle, Peitler 2019, 32, Abb. 2a-b); c) Varaždin; ZG 13427; 7.84 g; 20 mm; 9 h (photo by I. Krajcar); d) Podzemelj; Belokranjski muzej, Metlika 7254; 7.85 g; $20 \times 19.5 \mathrm{~mm} ; 9$ h (photo by M. Pavlovec).

Hence, it is now possible to add six sites to the already known twenty-six sites of discoveries of imitations of Alexander's staters.

In the area south and southwest of the lower course of the River Mura and south of the lower course of the River Drava, a welldocumented group appears of seven imitations of Alexander's staters from six sites. This is the southernmost group of imita- tions of Alexander's staters in Central Europe..$^{60}$ Of the six welldocumented coins, two coins were minted with the same dies, testifying to the local production of coins. Bilićs hypothesis that locally-produced imitations of Alexander's staters circulated in the area of north-western Croatia in the $3^{\text {rd }}$ century BC is thus further corroborated ${ }^{61}$

61 Bilić 2017, 228, 229. 


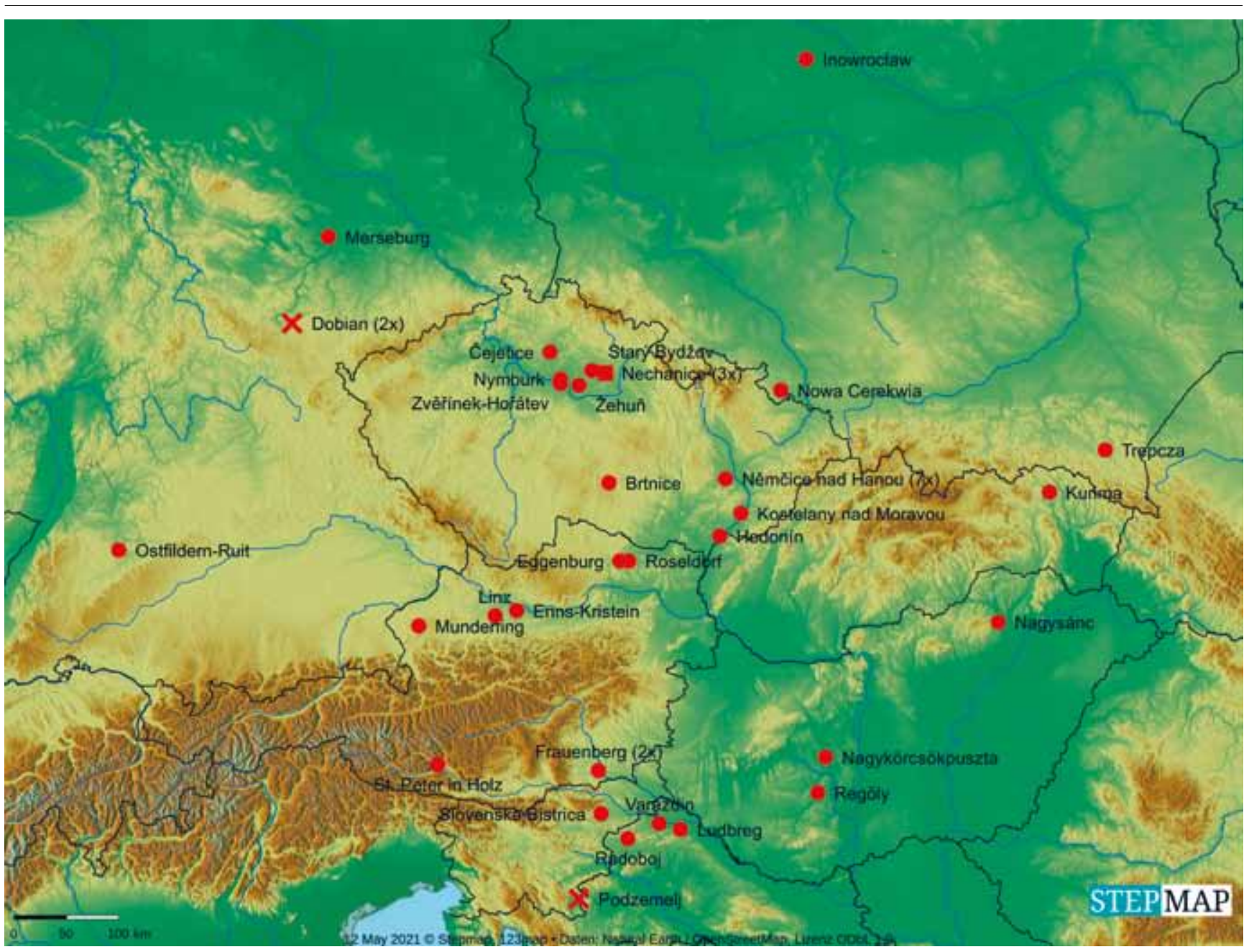

FIGURE 4. Sites of finds of Celtic gold coins of type Athena/Nike: $\bullet=$ single find; $\mathbf{X}=$ grave find; $\boldsymbol{\|}=$ coin hoard (by STEPMAP, adapted by P. Kos).

On the map I do not take into account the sites of Wrocław (Militký I:16.1/1(7) and Buj (Militký I:16.1/1(8), mapped by Militký 2018a, 19, Fig. 1), because there is no data referring to the denomination, as well as Vélké Pavlovice (Militký l:16.1/1(2)) and Holešov (Militký l:16.1/1(3)), since F. S. Kupido (1866, 144-146) was referring to gold coins of the Athena/Alkis type when mentioning these sites. From the map I have also omitted Etzersdorf (Militký 2018a,
54, coin I:15.1/1(1)), as, according to Dembski 1999, 108, no. 1, the coin in fact originates from Roseldorf. ${ }^{62}$ The coin of Militký group 16 (I:16.1/1(6)) from St Peter in Holz (Teurnia) should instead be listed in Militký group I:01, because of the accurate description of F. Pichler (1877, xcix), which indicates that the stater of the Amphipolis mint (330-320 BC) was used as the prototype (type Militký l:01.1/1). 


\section{BIBLIOGRAPHY}

Bilić 2012 - T. Bilić, Coin Circulation $3^{\text {rd }}$ Century BC - AD 193, in Migotti, B. (ed.), The Archaeology of Roman Southern Pannonia. The state of research and selected problems in the Croatian part of the Roman province of Pannonia, BAR International series 2393, Archaeopress, 2012, 359-388

Bilić 2017 - T. Bilić, Coin circulation in the pre-Imperial period in north-west Croatia, Vjesnik Arheološkog muzeja u Zagrebu 50, 2017, 223-253.

Castelin 1965 - K. Castelin, Die Goldprägung der Kelten in den böhmischen Ländern, Akademische Druck- und Verlagsanstalt, , 1965

Čižmář et al. 2008 - M. Čižmář, E. Kolníková, H.-Ch. Noeske, Němčice-Víceměřice, ein neues Handels- und Industriezentrum der Latenezeit in Mähren, Germania $86,2008,655-700$.

Dembski 1972 - G. Dembski, Die keltischen Fundmünzen Österreichs, Numismatische Zeitschrift 87-88, 1972, 37-73.

Dembski 1999 - G. Dembski, Münze oder Ware? Keltische Hackmünzen, Barren und Schrötlinge auf österreichischen Fundorten, in Bertók, K., Torbágyi, M. (eds.), Emlékkönyv Bíró- Sey Katalin és Gedai István 65. születésnapjára, Argumentum Kiadó, Budapest 1999, 107-122.

Dukat, Mirnik 1976 - Z. Dukat, I. Mirnik, Pre-Roman coinage on the territory of modern Yugoslavia, Bulletin of the Institute of Archaeology London 13, 1976, $175-210$

FMRD 13 - Laser, R., Stribny, K. (eds.), Die Fundmünzen der römischen Zeit in Deutschland, Abteilung 13, Thüringen, 2003.

Göricke-Lukić 2004 - H. Göricke-Lukić, Grčki, grčko-kolonijalni i keltski novac iz Muzeja Slavonije Osijek, Muzej Slavonije, 2004

Grahek, Kovač 2020 - L. Grahek, O. Kovač, Podzemelj - železnodobno središče v Beli krajini v luči novih raziskav / Podzemelj - an Iron Age centre in Bela krajina, in the light of new research, Arheološki Vestnik 71, 2020, 435-467.

Jandrasits 2014 - H. Jandrasits, Die Münzen der Boier im historischen Kontext, Netzwerk Geschichte Österreich, 2014, 44-53.

Klemenc, Saria 1936 - J. Klemenc, B. Saria, Archäologische Karte von Jugoslavien Blatt Ptuj, Akademie der Wissenschaften, 1936

Kolníková 2012 - E. Kolníková, Němčice. Ein Macht, Industrie- und Handelszentrum der Latènezeit in Mähren und Siedlungen am ihren Rande: kommentierter Fundkatalog. Münzen, Archeologický Ústav AV ČR, 2012.

Kos 1977 - P. Kos, Keltski novci Slovenije / Keltische Münzen Sloweniens, Situla 18, 1977, Narodni muzej Slovenije, 1977.

Ljubić 1880 - Š. Ljubić, Arkeologičke crtice, Viestnik hrvatskoga arkeologičkoga družtva 2, 1880, 110-120.

Ljubić 1890 - Š. Ljubić, Popis arkeologičkoga odjela Nar. zem. muzeja u Zagrebu. Odsjek 2, sv. 1, Numismatička sbirka od najstarije dobe do cara Dioklecijana, Narodni zemaljski muzej, 1890.

Militký 2018a-J. Militký, Keltské mincovnictví ve 3. a 2. století před Kristem v Čechách / Keltisches Münzwesen im 3.-2. Jh. V. Chr. in Böhmen, Archeologický ústav AV ČR, 2018

Militký 2018b - J. Militký, Celtic coins from the central site of Žehuň - Keltské mince $z$ areálu centrálního sídliště v Žehuni, Památky archeologické 109, 2018, $179-231$

Militký 2020 - J. Militký, Keltisches Münzwesen in Nordostosterreich, in Trebsche, P. (ed), Keltische Münzstätten und Heiligtümer. Die jüngere Eisenzeit im Osten Österreichs (ca. 450 bis 15 v. Chr.), Archäologie Niederösterreichs, Band 2, Verlag der österreichischen Akademie der Wissenschaften, 2020, 294321.

Mirnik 1989 - I. Mirnik, O blagu 15. Stoljeća iz Hrvatskog Zagorja / On a $15^{\text {th }}$ cen tury treasure from Hrvatsko Zagorje, Numizmatičke vijesti 42, 1989, 37-40.

Mirnik 1990 - I. Mirnik, O nalazima starog novca u Hrvatskom Zagorju, Obol 42, $1990,3-6$.
Mirnik 2008 - I. Mirnik, Die keltischen Münzen in Nordkroatien, in Balen-Letunić, D., Bader, T., Stork, S. (eds.), Dreitausend Jahre Vorgeschichte. Meisterwerke der Metallzeit im kontinentalen Kroatien, Schriftenreihe des Keltenmuseums Hochdorf/Enz 7, Keltenmuseum Hochdorf/Enz, 2008, 117-123.

Paulsen 1933 - P. Paulsen, Wikingerfunde aus Ungarn im Lichte der nord- und westeuropäische Frühgeschichte / Magyarországi Viking leletek az észak- és nyugateurópai kultúrtörténet megvilágításában, Archaeologia Hungarica 12, Ungarisches Nationalmuseum, 1933.

Paunov 2015 - E. Paunov, Introduction to the numismatics of Thrace, ca. 530 BCE-46 CE, in Valeva, J., Nankov, E., Graninger, D. (eds.), A companion to ancient Thrace, Wiley Blackwell, 2015, 265-292.

Pichler 1877 - F. Pichler, Studien über Teurnia, Mittheilungen der kaiserl. königl., Central-Commission zur Erforschung und Erhaltung der Baudenkmale 3, 1877, XCV-CXI.

Pink 1974 - K. Pink, Die Münzprägung der Ostkelten und ihrer Nachbarn, Klinkhardt \& Biermann Verlag, 2. Ergänzte und verbesserte Auflage, 1974

Polenz 1982 - H. Polenz, Münzen in latènezeitlichen Gräbern Mitteleuropas aus derZeitzwischen 300 und 50 vor Christi Geburt, Bayerische Vorgeschichtsblätter $47,1982,72-222$

Preda 1973 - C. Preda, Monedele Geto - Dacilor, Editura Academiei Republicii Socialiste România, 1973.

Price 1991 - J. Price, The coinage in the name of Alexander the Great and Philip Arrhidaeus. A British Museum catalogue, The Swiss Numismatic Society, The British Museum, 1991

Registar 1997 - Registar arheoloških nalaza i nalazišta sjeverozapadne Hrvatske (2. izd.), Muzejsko društvo sjeverozapadne Hrvatske, 1997

Salač 2015 - V. Salač, Urboiohaemum, Boiohaemum und Böhmen, in Karwowski, M., Salač, V., Sievers, S. (eds.), Boier zwischen Realität und Fiktion, Akten des internationalen Kolloquiums in Český Krumlov vom 14.-16.11.2013, Dr. Rudolf Habelt, 2015, 117-148.

Schrettle, Peitler 2019 - B. Schrettle, K. Peitler, Boische Goldmünzen aus der archäologischen Grabung am Tempelvorplatz im Jahr 2019, Sprechende Steine, Mitteilungsblatt des Archäologischen Vereines Flavia Solva 33, 2019, 30-34

Špoljar 2014 - D. Špoljar, Arheološki nalazi i nalazišta na području općine Radoboj, in Kozina, D. (ed.), Općina Radoboj, 2014, 25-42.

Špoljar 2015 - D. Špoljar, Naseljenost Radoboja i okolnih područja u prapovijesti / Settling of Radoboj and surrounding areas in prehistory, Kaj : časopis za književnost, umjetnost $i$ kulturu 48, 2015, 89-122.

Torbágyi 1991 - M. Torbágyi, Griechischer Münzumlauf im Karpatenbecken, Acta Archaelogica Academiae Scientarum Hungariae 43, 1991, 25-55.

Torbágyi 2016 - M. Torbágyi, After Enemonzo - reappraisal of the Transdanubian Celtic coinage, in Asolati, M., Callegher, B., Saccocci, A. (eds.), Suadente nummo vetere: studi in onore di Giovanni Gorini, Esedra, 2016, 127-136.

Ziegaus 1999 - B. Ziegaus, Die keltischen Münzen in den Gräbern von Dobian und Hostomitz, in Dubuis, O. F., Frey-Kupper, S., Perret, G. (eds.), Trouvailles monétaires de tombes. Actes du ze colloque international du Groupe suisse pour l'étude des trouvailles monétaires (Neuchâtel, 3-4 mars 1995), Les Editions du Zèbre, 1999, 107-118.

Ziegaus 2015 - B. Ziegaus, Boische Münzen in Süddeutschland - Fremde Prägungen mit überregionaler Gültigkeit?, in Karwowski, M., Salač, V., Sievers, S. (eds.), Boier zwischen Realität und Fiktion. Akten des internationalen Kolloquiums in Český Krumlov vom 14.-16.11.2013, Dr. Rudolf Habelt, 2015, 355-373. 